\title{
Low diagnostic yield of sural nerve biopsy in patients with peripheral neuropathy and primary amyloidosis
}

\author{
Zachary Simmons a, , Mila Blaivas ${ }^{\text {b }}$, Arnold J. Aguilera c, Eva L. Feldman ", \\ Mark B. Bromberg ${ }^{\mathrm{a}}$ and Javad Towfighi ${ }^{\mathrm{d}}$ \\ Departments of ${ }^{a}$ Neurology and ${ }^{b}$ Pathology, The Unuersity of Michigan. Ann Arbor, MI 48109, USA, ' Department of Neurologv. \\ Geisinger Medical Center, Danulle, PA 17822, USA, and d Department of Pathology, Pennsyluania State Unulersity College of Medicine, \\ Hershey Medical Center, Hershev, PA 17033. USA \\ (Recelved 10 February, 1993) \\ (Revised, received 2 June, 1993) \\ (Accepted 11 June, 1993)
}

Key words· Neuropathy; Peripheral nerve diseases, Amyloidosıs; Sural nerve

\section{Summary}

Patients with primary amyloidosis may develop peripheral neuropathy as an early feature Sural nerve biopsy is reported to be a sensitıve method for diagnosing amyloidosis in such patients. We identified nıne patients, ultımately diagnosed as having amyloidosis, who were referred for peripheral neuropathy of undetermined etrology. In six, a sural nerve bropsy demonstrated no amyloid Subsequent examination of other tissue or of the contralateral sural nerve eventually resulted in the correct diagnosis. We conclude that sural nerve biopsy may be less sensitive than previously believed for the diagnosis of amyloidosis in patients with peripheral neuropathy secondary to amyloid. When the clinical suspicion of amyloidosis is high. a nondiagnostic sural nerve biopsy should not discourage the performance of further investigative studies

\section{Introduction}

Primary amyloidosis is a disorder in which the fibrous protein amyloid may be deposited in virtually any tissue (Kyle and Greipp 1983; Cohen 1991). Since peripheral neuropathy is frequently an early or presenting feature of amyloidosis (Kyle and Bayrd 1975; Kyle and Greipp 1983; Duston et al. 1989), the neurologist may be called upon to evaluate patients who are ultimately found to have amyloidosis, but in whom this diagnosis has not yet been established. Previous series (Kelly et al. 1979; Kyle and Greipp 1983; Janssen et al. 1986) have indicated a high diagnostic yield from sural nerve biopsy in patients with primary amyloidosis and peripheral neuropathy. We have recently evaluated 9 patients for perıpheral neuropathy of unclear etiology who were eventually diagnosed as having amyloidosis.

Correspondence to Zachary Simmons, MD, Division of Neurology, Pennsylvania State University College of Medicine, Hershey Medical Center, Hershey, PA 17033, USA Tel- (717) 531-8692, Fax (717) 531-7557

${ }^{1}$ Present address Division of Neurology, Pennsylvania State UnIversity College of Medicine, Hershey Medical Center, Hershey, PA 17033, USA
In 6 of these patients, Congo red or crystal violet staining of sural nerve biopsy sections as well as electron microscopy falled to show amyloid deposits. This raises questions regarding the sensitivity of routine sural nerve biopsy in the diagnosis of amyloidosis, and emphasizes the need for further diagnostic workup of patients with neuropathy whose clinical presentations and laboratory studies suggest amylordosis, but in whom routine studies of sural nerve are nondiagnostic.

\section{Materials and methods}

We reviewed records of the University of Michigan Neuromuscular Clinic and the Geisınger Medical Center Department of Neurology for the past 6 years, and identified 9 patıents referred for peripheral neuropathy of undetermined etiology who were eventually diagnosed as having amyloidosis. Amyloid was demonstrated in the initial rectal biopsy in 2 patients and the initial sural nerve biopsy in one. The remaining 6 patients are the subjects of this report

None of the patients had systemic cancer, a history of excessive alcohol use, or other disorders known to cause neuropathy except for one patient (patient 3), 
who had mild diabetes mellitus which was controlled by diet alone. All had undergone comprehensive evaluations to rule out other causes of neuropathy, including physical examination, complete blood count, Westergren sedimentation rate, ANA, glucose, electrolytes, BUN, creatınine, liver function tests, T4, TSH, vitamin $\mathrm{B}_{12}$ level, VDRL or RPR, and chest X-ray. High resolution agarose gel serum electrophoresis, immunoglobulın quantification, determination of kappa: lambda light chain ratio, and if necessary immunofixation of serum (Keren et al. 1988) were performed in 5 of the patients, while one underwent serum immunoelectrophoresıs.

Sural nerve biopsies, taken at the level of the ankle, were divided into 2 sections immediately after surgery The portion for light microscopy was fixed in $10 \%$ formalin. One longitudinal and 1-3 cross-sections were then obtained and embedded in paraffin. These blocks were then cut at 2 or more levels. All were stained with hematoxylın-eosin and with a stain for amyloıd (crystal violet in patıent 4 , Congo red in the others). Trichrome staining was also employed in all except patient 6 . For all patients, another portion of nerve was fixed in glutaraldehyde and divided into 2 sections. One section was minced and the pieces embedded in Epon, and the other was processed in glycerol for teasing. At least 10 blocks of epon-embedded material were examined on multiple 1 micron thick toluidine-stained sections, and one or two of them were selected for electron mlcroscopy All biopsies were reviewed by a neuropathologist (M.B. or J.T.)

\section{Case reports}

Two illustrative cases are described.

Pattent 2

An 83-year-old man was admitted with a 6-month history of bilateral hand pain and arm weakness He had surgical treatment for bilateral carpal tunnel syndromes 3 years previously and a cholecystectomy for abdominal pain 2 years previously On examination, there was diffuse mild upper and lower extremity weakness Achilles reflexes were absent Pinprick and vibration were decreased distally Serum protein electrophoresis and immunofixation revealed an IgM lambda monoclonal gammopathy Bone marrow biopsy was normal

\section{TABLE 1}

\section{CLINICAL AND HISTOLOGICAL FINDINGS IN PATIENTS WITH POLYNEUROPATHY AND AMYLOIDOSIS}

\begin{tabular}{|c|c|c|c|c|c|c|c|}
\hline \multirow[t]{2}{*}{ Patıent No } & \multirow{2}{*}{$\begin{array}{l}\text { Age at } \\
\text { onset } / \text { sex }\end{array}$} & \multicolumn{3}{|c|}{ Sural nerve biopsy } & \multicolumn{3}{|l|}{ Other tissue studied } \\
\hline & & $\begin{array}{l}\text { Symptom } \\
\text { duration at } \\
\text { biopsy }\end{array}$ & $\begin{array}{l}\text { Biopsy } \\
\text { findings }\end{array}$ & $\begin{array}{l}\text { Amyloid } \\
\text { (Congo red } \\
\text { and EM) }\end{array}$ & Type of tissue & $\begin{array}{l}\text { Time after } \\
\text { sural nerve } \\
\text { biopsy }\end{array}$ & $\begin{array}{l}\text { Amyloid } \\
\text { (Congo } \\
\text { red) }\end{array}$ \\
\hline 1 & $62 / F$ & 10 months & $\begin{array}{l}\text { Severe loss of } \\
\text { small }>\text { large } \\
\text { myelinated } \\
\text { axons }\end{array}$ & Negative & Rectal bıopsy & 1 month & Positive \\
\hline 2 & $82 / M$ & 36 months & $\begin{array}{l}\text { Moderate loss } \\
\text { of small > large } \\
\text { myelınated } \\
\text { axons }\end{array}$ & Negative & $\begin{array}{l}\text { Transbronchial bıopsy of } \\
\text { lung mass }\end{array}$ & 5 months & Positive \\
\hline \multirow[t]{2}{*}{3} & $64 / \mathrm{M}$ & 15 months & $\begin{array}{l}\text { Severe loss of } \\
\text { all myelinated } \\
\text { axons }\end{array}$ & Negative & Contralateral sural nerve & 4 months & $\begin{array}{l}\text { Negative } \\
\text { (Positive } \\
\text { by EM) }\end{array}$ \\
\hline & & & & & Ileum from ileostomy & See text & Positive \\
\hline \multirow[t]{2}{*}{4} & $66 / M$ & 16 months & $\begin{array}{l}\text { Moderate loss } \\
\text { of all myelınated } \\
\text { axons }\end{array}$ & Negatıve * & First rectal biopsy & 13 months & Negative \\
\hline & & & & & $\begin{array}{l}\text { Second rectal bıopsy } \\
\text { Autopsy brachıal plexus, } \\
\text { femoral nerve, phrenıc } \\
\text { nerve, dorsal root ganglıon }\end{array}$ & $\begin{array}{l}16 \text { months } \\
21 \text { months }\end{array}$ & $\begin{array}{l}\text { Positive } \\
\text { All positive }\end{array}$ \\
\hline 5 & $66 / M$ & 6 months & $\begin{array}{l}\text { Moderate loss } \\
\text { of small }>\text { large } \\
\text { myelinated axons }\end{array}$ & Negatıve & Autopsy brachial plexus & 10 months & Positive \\
\hline 6 & $68 / M$ & 5 months & $\begin{array}{l}\text { Marked loss of } \\
\text { small > large } \\
\text { myelınated axons }\end{array}$ & Negative & $\begin{array}{l}\text { Autopsy obturator nerve, } \\
\text { anterior and posterior } \\
\text { roots, heart }\end{array}$ & 11 months & All positive \\
\hline
\end{tabular}


Two skeletal surveys showed no bone lesions Electrodiagnostic studies revealed an axonal polyradiculoneuropathy Sural nerve bıopsy was negative for amylord by Congo red staining and by electron microscopy A lung mass was identified, and he underwent transbronchial bıopsy which demonstrated amyloıd

\section{Pattent 6}

A 68-year-old man presented with a 4-month history of burning paresthesıas of the distal lower extremitıes and fingertıps, accompanied by midlıne abdominal numbness. Examınation revealed mild weakness of foot dorsiflexors and toe extensors Patellar reflexes were depressed, and Achilles reflexes were absent These was decreased sensation to pin, light touch, and vibration in the distal lower extremities, and decreased pin and light touch sensation in the midlıne abdomen Serum and urıne immunoelectrophoreses were normal Electrodiagnostıc studies revealed an axonal polyneuropathy Sural nerve biopsy was negative for amylord by Congo red staining and by electron microscopy Sensory and motor deficits progressed and he died suddenly At autopsy, amyloid deposition was demonstrated in obturator nerve, anterior and posterior nerve roots, and heart

\section{Results}

Data from the 6 patients studied are presented in Table 1. The youngest was 62 years old and 5 were male. All presented with dysesthetic limb pain and numbness. Strength varied from normal to severely impaired, and sensory loss was present in all. Four had monoclonal heavy or light chains in serum or urine. None was known to have amyloidosis at the time of presentation, and none had features of other organ involvement at that time

The presence of a painful sensorımotor neuropathy, often with a monoclonal gammopathy, led to consideration of amyloid neuropathy in all patients. Sural nerve was the first tissue evaluated for amyloid in all. The tıme from onset of symptoms to sural nerve biopsy varied from 5 to 36 months. All biopsies revealed an axonal neuropathy, and none demonstrated amyloid.

After the nondiagnostic sural nerve biopsy, amylond was eventually identified in all patients by biopsy of other tissue or at autopsy 1 to 21 months after the initial sural nerve biopsy. Patient 3 was the only one to undergo a second sural nerve biopsy. While the first one was negative for amyloid, the second one, obtained 4 months later, contained very small amounts of amyloid on electron microscopy Patient 3 also was unique In that one other tissue which eventually was found to stain positive for amyloid (ileum) was actually obtained at another institution 2 months prior to the first sural nerve biopsy (13 months after onset of symptoms), but was not stained for amyloid at that time. Once we suspected amyloidosis but were unable to demonstrate it on sural nerve biopsy, the ileal tissue previously removed was obtained and stained with Congo red, resulting in a diagnosis of amylordosis

\section{Discussion}

Peripheral neuropathy occurs in $13-35 \%$ of patients with primary amyloidosis, may be the presenting symptom of the disease, and may be present for months to years before the diagnosis of amylordosis is established (Kyle and Bayrd 1975; Kyle and Greipp 1983; Duston et al. 1989). Our patients possessed clinical features consistent with amyloid polyneuropathy, and some had monoclonal gammopathies. In such patients, a sural nerve biopsy frequently is performed to look for amyloid deposits

The yield of sural nerve biopsy in patients with primary amyloidosis and peripheral neuropathy is said to be high. One small series (14 patients) cited a yield of $86 \%$ (Kyle and Dyck 1993). A figure of over $90 \%$ has also been cited (Kelly 1985). Review of other data suggests that the yield may even approach $100 \%$ (Kelly et al. 1979; Kyle and Greipp 1983, Janssen et al. 1986). However, such data are derived from small numbers of patients.

Our yield, while also based on a small number of patients, is strikingly lower. One factor which may account for this is the timing of the biopsy relative to the pattern of amylond deposition within the peripheral nervous system. Proximal portions of the peripheral nervous system are thought to be involved first, followed by breakdown of the blood-nerve barrier and distal amyloid deposition (De Navasquez and Treble 1938; Verghese et al. 1983, Hanyu et al. 1989; Sobue et al. 1990; Antoine et al. 1991). Thus, a patient studied early in the course of amyloidosis may show amyloid deposition only in the proxımal perıpheral nervous system. A study later in the illness may demonstrate amyloid more distally. Such a pattern of amyloid deposition would explain not only our inital nondagnostic sural nerve biopsy results, but also the presence of amyloid in the contralateral sural nerve of patient 3 several months later and the presence of amyloid in proxumal nerve of two of our patients at autopsy. The high yield of sural nerve biopsies previously reported in amyloidosis (Kelly et al 1979; Kyle and Greipp 1983 , Janssen et al. 1986; Kyle and Dyck 1993) may have resulted from a longer duration of peripheral nervous system involvement prior to the time of nerve biopsy, although such data cannot be extracted from those reports. The duration of symptoms in our patients at the time of sural nerve biopsy varied from 5 to 36 months, which we believe is representative of the tume a sural nerve biopsy usually would be obtaned in such patients.

Technical factors must be considered when comparing our low yield of sural nerve biopsy to the higher values previously published. Techniques for evaluating sural nerve biopsies vary from institution to institution. Because this was a retrospective study. control for 
bıopsy technique and specimen handling was not possible Amylord deposition withın a nerve may be patchy, and possibly our yield could have been increased by the use of very large numbers of sections per nerve or staining for both Congo red and crystal violet. However, this is often not practical in the usual clinical setting, and there is no data to indicate how helpful this might be We believe that our protocol for the processing and study of sural nerve biopsies, resulting in the review of cross and longitudinal Congo red or crystal violet sections as well as multiple sections for electron microscopy, reflects the type of evaluation performed routinely in large institutions, so that our figures are of interest to clinıcians and neuropathologists involved in the management of such patients A prospectıve study comparing technıques such as ours to other means of processing sural nerve biopsies would be helpful to address this issue.

Although our series is small, these cases suggest the need for persistence in diagnostic workup if amylordosis is strongly suspected as the cause of peripheral neuropathy, since the yield of routinely processed sural nerve biopsies in the diagnosis of amyloidosis may be lower than previously believed When patients, particularly older males, present with a painful neuropathy and a monoclonal protein in the serum or urine, the sural nerve biopsy may show only nerve fiber loss. In such cases, biopsy of additional tissue or eventually of the contralateral sural nerve may lead to an accurate diagnosis.

\section{References}

Antorne, J C, Barıl, A, Guettier, C, Barral, F.G, Bady, B . Convers, $\mathrm{P}$ and Michel, D (1991) Unusual amyloıd polyneuropathy with predominant lumbosacral nerve roots and plexus involvement Neurology, 41 206-208

Cohen, A S (1990) Amyloidosis In Willams, W J, Beutler, E, Erslev, A J. and Lichtman, M A (Eds.), Hematology, 4th ed., McGraw-Hill, New York, pp 1148-1157

De Navasquez, $S$ and Treble, H.A (1938) A case of primary generalized amylord disease with involvement of the nerves Brain, 61 $116-128$

Duston, M A, Skınner, M, Anderson, J and Cohen, A S (1989) Peripheral neuropathy as an early marker of $\mathrm{AL}$ amyloudosis Arch Intern Med., 149. 358-360

Hanyu, N, Ikeda, S, Nakadai, A, Yanagisawd, N and Powell, H (1989) Perıpheral nerve pathological findıngs in famulial amyloıd polyneuropathy a correlative study of proximal sciatic nerve and sural nerve lesions Ann Neurol, 25 340-350

Janssen, S, Van Rıjswıjk, M H, Meıjer, S, Ruınen, L. and Van Der Hem, G K (1986) Systemic amyloidosis a clınical survey of 144 cases Neth J Med, 29 376-385.

Kelly, J J (1985) Peripheral neuropathies associated with monoclonal protems a clinical review Muscle Nerve, 8 138-150

Kelly, J J , Kyle, R A, O'Brien, P C and Dyck, P J (1979) The natural history of peripheral neuropathy in primary systemic amyloidosis Ann Neurol, 6 1-7

Keren, D F, Warren, J S and Lowe, J B (1988) Strategy to diagnose monoclonal gammopathies in serum high-resolution electrophoresıs, Immunofixation, and $\mathrm{k} / 1$ quantification Clın Chem , $34 \quad 2196-2201$

Kyle, R A and Bayrd, ED (1975) Amyloıdosis review of 236 cases Medicine, 54 271-299.

Kyle, R A and Dyck, P J (1993) Amyloıdosis and neuropathy In Dyck, P J . Thomas, P K, Griffin, J W, Low, P.A and Poduslo, J F (Eds). Perıpheral Neuropathy. W B Saunders, Philadelphia, PA, pp 1294-1309.

Kyle, R A and Greıpp, P R (1983) Amyloıdosıs (AL) Clınıcal and laboratory features in 229 cases Mayo Clin Proc, 58: 665-683

Sobue, G, Naokı, N, Murakamı, K, Yasuda, T, Sahashı, K., Mıtsuma, T. Sasakı, H, Sasakı, Y. and Takahashı, A (1990) Type I familial amyloid polyneuropathy Brain, 113 903-919

Verghese, J P , Bradley, W G, Nemnı, R and McAdam, K P W J (1983) Amyloıd neuropathy in multiple myeloma and other plasma cell dyscrasias J. Neurol Scı, 59 237-246. 